\title{
EVALUATION OF BIOTECHNOLOGY IN THE CONSERVATION OF WALL PAINTINGS IN THE MORTUARY TEMPLE OF RAMSES III.
}

\author{
Abd El Aal, Sh. \\ Lecturer, Conservation dept., Faculty of Archaeology, Fayoum University, Egypt. \\ E-mail:smm00@fayoum.edu.eg
}

\begin{abstract}
Egypt has a lot of ancient tombs and tempels, which were decorated with different kinds of wall paintings. Structure of these wall pintings consists of support, plaster and paint layers. The mortuary temple of Ramses III the king of $20^{\text {th }}$ Dynasty who ruled Egypt for 31 years (1183-1153 B.C). It's located of on the west bank of Luxor, Upper Egypt; The temple itself is made of sandstone and contains more than 75,000 square feet of wall decoration and reliefs.Paintings deterioration is primarily due to physiochemical, natural and human factors. The most detrimental factors are bat patches, old varnish and organic waste of birds. All these leed to the gradual disappearance of paintings. Modern technology of conservation is focused on application of new materials for cleaning of wall paintings. Here we report on the use of enzymes for cleaning surface of wall paintings. Analytical techniques such as PIXE, MPIXE, XRD, FTIR and Optical Microscopy were used to evaluate the enzymatic cleaning processes of wall paintings and to identify the chemical composition of blue, red, yellow and white pigments. PIXE and XRD results indicated that there is no change in the chemical composition of the materials and pigments. FTIR and OM results confirmed the stability of organic medium before and after enzymatic cleaning of different kind of patches.
\end{abstract}

Keywords: Biotechnology, Conservation, Wall paintings, Enzymes, PIXE, FTIR.

\section{Introduction}

Medinet Habu is the name commonly given to the Mortuary Temple of Ramesses III, an important archeological site from New Kingdom period, located in the place of same name on the west bank of Luxor in Egypt. Aside from its intrinsic size and architectural and artistic importance, the temple is probably best known as the source of inscribed reliefs depicting the advent and defeat of the Sea Peoples during the reign of Ramses III. The temple precinct measures approximately $700 \mathrm{ft}(210 \mathrm{~m}) \times 1,000 \mathrm{ft}$ $(300 \mathrm{~m})$ and contains more than
$75,350 \mathrm{sq} \mathrm{ft} \quad\left(7,000 \mathrm{~m}^{2}\right)$ of decorated wall reliefs [1]. Its walls are relatively well preserved and it is surrounded by a massive mud brick enclosure, which may have been fortified. The original entrance is through a fortified gatehouse, known as a migdol (a common architectural feature of Asiatic fortresses of the time). Some of them are in extremely bad condition. [2] [3]. Disfiguration of the surface is due to the application of varnish layer on the surface after the revealing stage; this varnish has caused the darkening of the surface of the painting. Other damage 
forms are found such as soot layers, dust, wax, micro cracks, and salts. The mortuary temple of Ramses III was selected for this study which involves using enzymes for cleaning. The aim is to study the effect of enzymes on painted surfaces. PIXE was used to examine and analyze the components of the paintings before and after treatment. PIXE is one of the most sensitive micro analytical methods [4]. It is nondestructive and is currently used for multi-elemental analysis both in vacuum and in air. The "in vacuum"

\section{Materials and Methods}

Minute samples from several locations were collected to study the layer structure of the selected mural paintings, the thickness and composition of each layer, the inner status of both cases, and the preservation state of the paint layer. In the current study, samples were collected from areas which suffer from deterioration factors and subjected to examination and analysis techniques. These samples contain some pigments, ground layer, paint layer and coating layer (varnish + soot + blood) were analyzed thorough same investigation techniques. Optical microscopy model Axiotron Zeiss Optical Microscope was used to investigate the surface of samples and to identify the relationship between the layers of wall paintings and the size of grains [8] [9] at the Institute of Electronic Materials Technology (ITME) in Warsaw and Forschungszentrum Dresden (FZD) under magnification between $3.2 \times 6.5 \times$. Within the same context pigments and layer structure samples were also studied to evaluate their thickness, composition, their inner status and the preservation state of the paint layer. Broad beam PIXE analysis with $1.0 \mathrm{MeV}$ protons was performed at SINS, Warsaw using the Lech Van de Graff accelerator. Protons prior to entering the target chamber were collimated by two graphite collimators mode has the advantage of detecting low atomic number elements [5]. $\mu$ PIXE used to give high resolution elemental maps and analysis one grain of pigments. [6] [7]. X-ray diffraction was used to identify components of the ground layer and pigments present in both cases. Fourier transform infrared spectroscopy (FTIR) was used to identify the type of varnish and to detect the presence or absence of the paint media. The study cases were also examined under a light microscope and polarizing microscope.

with a diameter of $1 \mathrm{~mm}$. The beam current was between $5 \mathrm{nA}$ and $20 \mathrm{nA}$, the total charge during the irradiation ranged from $0.1 \mathrm{mC}$ to $0.5 \mathrm{mC}$. The $\mathrm{X}$-rays generated in the samples were measured by a $7 \mathrm{~mm}^{2}$ Amptek Inc. (Bedford, USA) $\mathrm{Si}$ (Li) detector with a $25 \mathrm{~mm} \mathrm{Be}$ window, placed at 90 or 180 to the beam direction outside the experimental chamber and an energy resolution (FWHM) of 180-200 eV at $6.4 \mathrm{keV}$ (checked during experimental runs by an 241Am standard radioactive source). Samples with dimensions from $2 \times 3 \mathrm{~mm}$. up to $10 \times 10 \mathrm{~mm}$ were mounted on 8 position target holder perpendicular to the beam direction for analysis. Rotation of the target holder by $180 \mathrm{deg}$ enables sample analysis from both sides i.e. front and back. This was especially important for samples with a discontinuous paint layer. X-ray powder diffraction patterns were obtained using a Bruker AXS D8 Advance diffractometer in BraggBrentano geometry equipped with a $\mathrm{Cu}$ sealed-tube radiation source $(\lambda=1.54178$ $\AA)$ and a secondary beam graphite monochromator. Finally, FTIR spectra were recorded on a Perkin-Elmer Spectrum GX FTIR system with samples prepared as $\mathrm{KBr}$ pellets, in the 4000 to $370 \mathrm{~cm}-1$ range, at a resolution of $4 \mathrm{~cm}-$ 1. The collected spectra have been expressed by absorbance units and baseline has been corrected. 


\section{Results}

\subsection{Optical microscopy}

Examination of both cases by optical microscope reveals the following:

1. Samples suffer from several deterioration of its structural coherence. Images show surface damage in the form of blood patches, soot, dust, salts, and varnish layer used during previous conservation of the painting in the past. All previous forms have covered the paint layer preventing the viewing of the scene.

\section{2. .Polarizing microscope}

The photomicrograph result indicated that red pigment sample from mural painting is non homogeneous in thickness, perhaps due to some mistakes during the preparation of the paint layers or presence of varnish overpainting layers. There are also black spots due to soot. In the yellow

\subsection{PIXE analysis}

The final evaluation of data was performed for the spectrum resulting from subtraction of that taken for front side (face) from the other for the support (back). This procedure made it possible to perform qualitative analysis even of partially flaked off paint layer. Results obtained from PIXE analysis of the samples from the mural painting show that the paint layers contain the following elements: $\mathrm{Si}, \mathrm{S}, \mathrm{Ca}, \mathrm{Ti}, \mathrm{Fe}$, and $\mathrm{Zn}$. The ground layer was found to consist of $\mathrm{Si}, \mathrm{S}, \mathrm{Cl}, \mathrm{Ca}, \mathrm{Ti}$, and $\mathrm{Fe}$. The main element that forms the red pigment is $\mathrm{Fe}$ and other elements such as $\mathrm{Ti}, \mathrm{Mn}$, and $\mathrm{Zn}$ have been added to reach a specific red hue. The results of the PIXE analysis have led to the following conclusions:

1. Red paint contains $\mathrm{Fe}$ as a major element, which points to hematite as a pigment. 2. Other detected elements found in the paint pigment in some samples are due to some additives used
2. The presence of crystalline salts inside the layer structure of the mural painting has caused the lost of painting structural coherence and consequently pigments pilling off.

3. The grains of the red (hematite) and yellow pigments are extremely fine (less than $1 \mu \mathrm{m}$ size) as a result of hematite being a very fine earth mineral as well as the good grinding process

pigment sample from mural painting there is a white coating of one painted layer and the color layer is very thin and tends to red confirming the presence of iron. Ground layer is very homogeneous and the grain of mortar layer appears clearly.

to obtain a darker or lighter red hue. Manganese was added in the form of $\mathrm{MnO}$ to obtain dark red color. On the other hand, $\mathrm{Ti}$ and $\mathrm{Zn}$ oxides were added to obtain a light red color.

3. Yellow paint contains $\mathrm{Fe}$ that is a strong indication of that the used pigment is goethite $\mathrm{FeO}(\mathrm{OH})$. Other elements were also added to darken or lighten the yellow color.

4. The presence of chlorine $(\mathrm{Cl})$ reveals the contamination with salt $(\mathrm{NaCl}) .5$. Finally the elements detected in ground layers are $\mathrm{Si}, \mathrm{S}, \mathrm{Ca}$, and $\mathrm{Cl}$. This leads to the conclusion that quartz, calcium sulphate (gypsum), and calcium carbonate were used to make the ground layer. The presence of salt. $(\mathrm{NaCl})$ has also been confirmed. 6. Blue pigment sample contains $\mathrm{Cu}, \mathrm{Si}$ and $\mathrm{Ca}$ as major elements, which refer to Cuprorivaite $\left(\mathrm{CaCuSi}_{4} \mathrm{O}_{10}\right) \quad$ called Egyptian Blue, all of these features are shown figs. $(1 \& 2)$ 


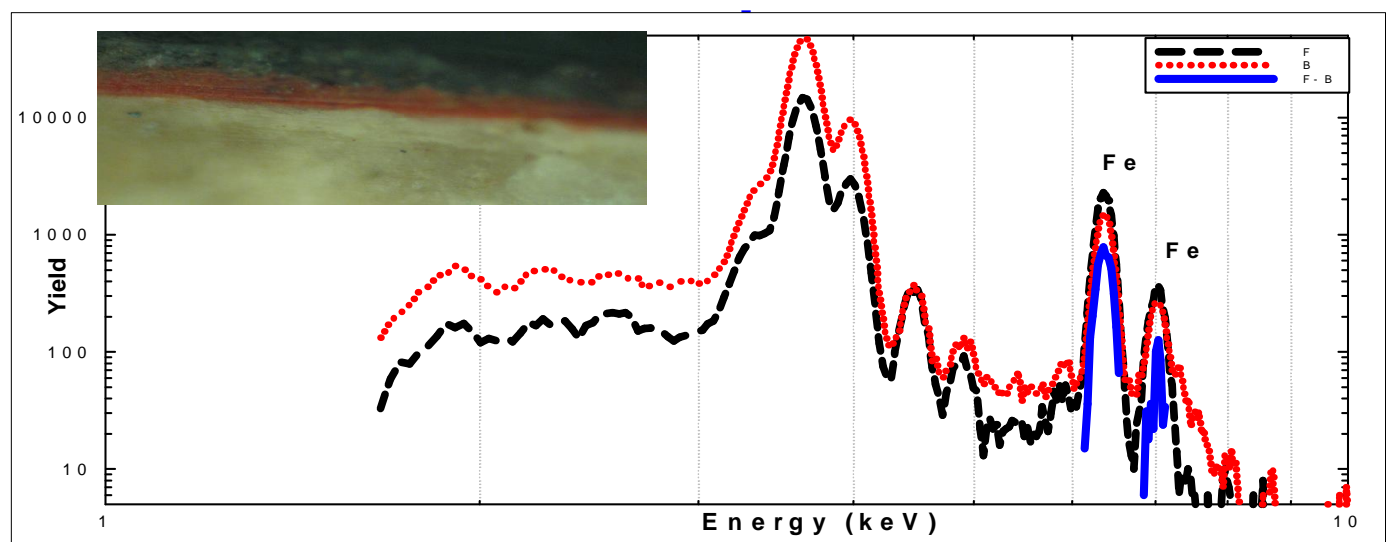

Figure (1) Optical microscopy image of dark red sample from the mortuary temple of Ramses III. (1186-1155 BC, $20^{\text {th }}$ dyn.), showing red painted layer, dirties and soot on the surface of the sample, results of PIXE analysis of the same sample and PIXE spectra of face, back and deference between face and background which can identify Fe.

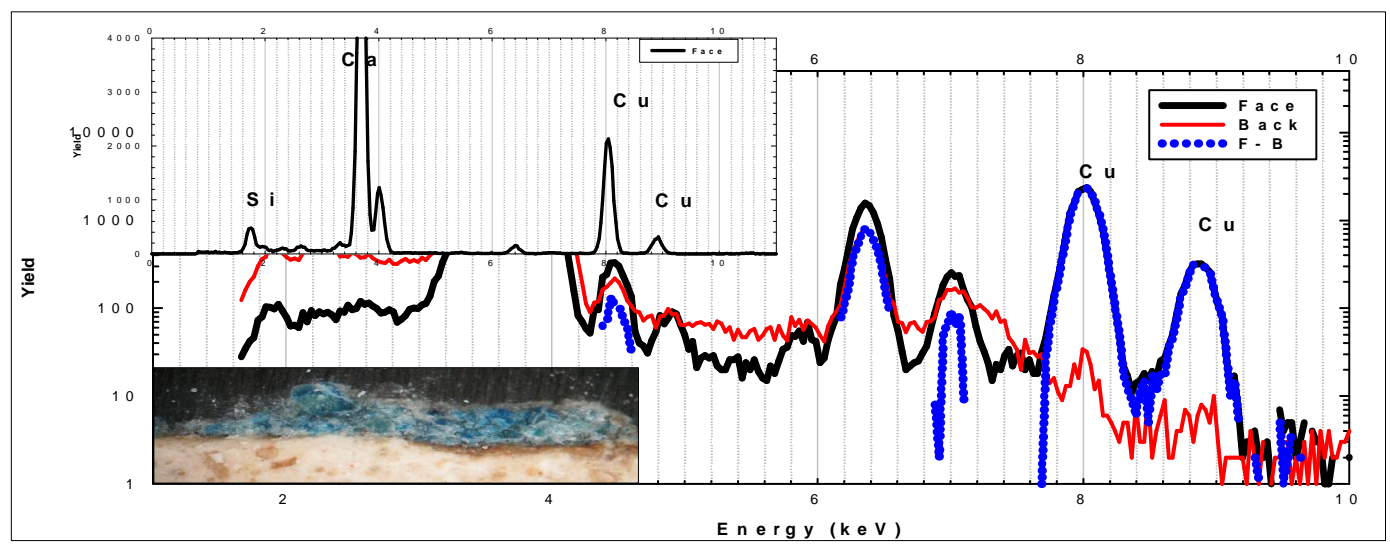

Figure (2) Results of PIXE analysis of blue sample from the mortuary temple of Ramses III. PIXE spectra of face and background and deference between it, this can identify some of elements $\mathrm{Ti}, \mathrm{Fe}$, and $\mathrm{Cu}$. $\mu$ PIXE spectra scanning of face, this can identify some of elements $\mathrm{Si}, \mathrm{S}, \mathrm{Cl}, \mathrm{Ca}, \mathrm{Mn}, \mathrm{Fe}$, and $\mathrm{Cu}$. Optical microscopy investigation of sample cross section showing the layer and thickness of painted layer.

\subsection{XRD analysis}

The results of the XRD analysis have led to the following conclusions: 1 . Red paint contains iron oxide as a major element, which points to hematite as a pigment. 2. Other detected elements found in the paint pigment in some samples are due to some additives used to obtain a darker or lighter red hue. Manganese was added in the form of $\mathrm{MnO}$ to obtain dark red color. On the other hand, $\mathrm{Ti}$ and $\mathrm{Zn}$ oxides were added to obtain a light red color. 3. Blue

\subsection{FTIR analysis}

The IR results were performed over the normalized spectra FTIR technique is applied to determine the functional groups present in the samples. The result

samples detected that cuprorivaite as the main compounds which refer to cuprorivaite $\mathrm{CaCuSi}_{4} \mathrm{O}_{10}$ Egyptian Blue. 4. The ground layers were found of samples consists of $\mathrm{CaCO}_{3}$ as calcium carbonate and $\mathrm{CaSO}_{4}$ as calcium sulphate and $\mathrm{SiO}_{2}$ as quartz and the ground layers of all samples consist of a single layer with exception of light red sample, which have ground layer, plaster layer and painting layer.

of the studied samples before treatment showed that animal glue was used as a varnish layer. The spectra obtained for studied samples were compared with 
those of animal glue standards, fig (3). FTIR confirmed that Arabic gum was used as an organic binding medium; it means that the used technique is tempera technique.

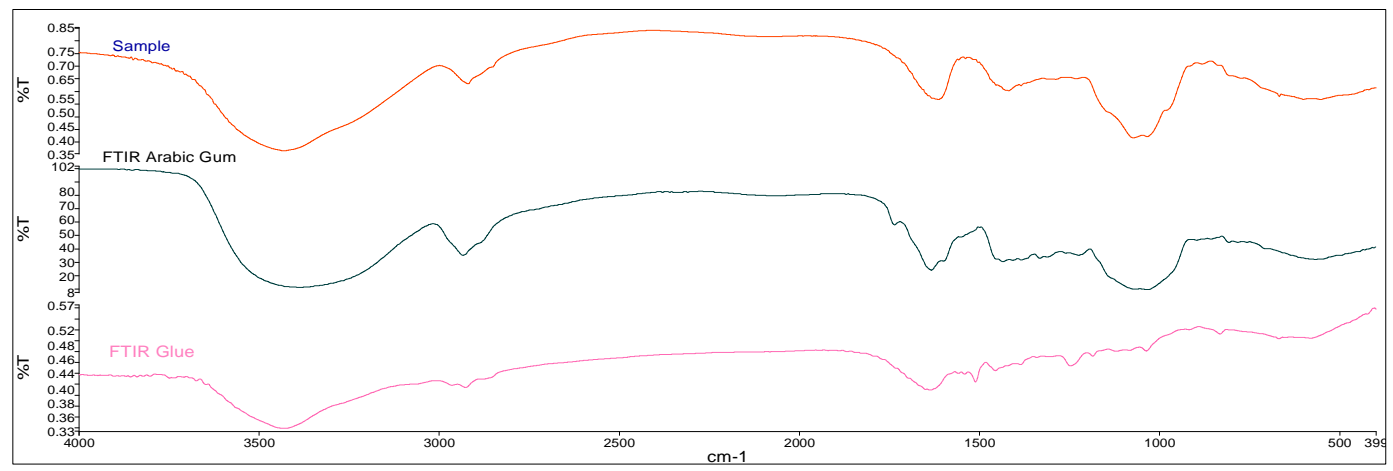

Figure (3) FTIR spectra of organic binders in wall paintings compared with Arabic gum spectra

\section{Use of enzymes.}

Enzymes are proteins found in all living cells where they, as disintegration catalysts, regulate metabolic processes. They catalyse disintegration of organic materials into simpler compounds thus enabling or accelerating chemical processes. Once the reaction is completed, the enzyme remains unchanged and it is ready for the next reaction. This is repeated throughout its shelf life. However, the shelf life of enzymes is limited, and enzymes that are used for cleaning purposes are usually used only once. The action of enzymes is very specific. Theoretically, each type of enzyme can disintegrate or synthesize only one specific material. In some cases, they limit their action to specific bonds in the material that they affect. For example, most lipases can cause disintegration of most types of oils and fats. However, depending on the applied enzyme, they will act only on specific bonds. Enzyme mixtures can be prepared for the disintegration of chemical bonds in heterogeneous molecular compounds of oils and fats. Biological degradation of oils and fats with enzymes in the secondary phase of microbial metabolism is a key factor in the construction of precursor molecules. The first step in the metabolism of oils and fats is the hydrolysis of triacylglycerol with lipases. The resultant products are three fatty acids and a glycerol molecule. The glycerol molecule enters, without any major difficulties, the glycolysis cycle, whereas the molecules of fatty acids enter the cyclic process of oxidation, where each is reduced by two atoms of carbon. This process is called $\beta$-oxidation. Before entering the $\beta$-oxidation process, fatty acids should be reoriented to the 'activated form of fatty acid' or acyl coenzyme A. The activation of this form of fatty acid occurs in the presence of magnesium ions, ATP molecules, coenzymeA and acyl coenzyme. Synthesis by enzymes is also very specific for the environment in which they act. Each enzyme is an active catalyst only if optimal $\mathrm{pH}$ and/or temperature are achieved. The optimal activity $\mathrm{pH}$ and temperature depend on each specific enzyme. In the case of commercial enzymes, the information about their optimal activity is given by the manufacturer in the documentation, or this information can be found in one of the relevant Internet databases. Enzymes are not active in adverse conditions. Enzymes that can be used for the cleaning of paint surfaces (primarily those produced for the detergent industry) can be classified into four basic groups: amylases, cellulases, lipases and proteases. However, this is only a rough classification since some enzymes can have properties of more than one group. Amylases are primarily used for the 
disintegration of molecular bonds of polysaccharides, such as vegetable gums and starch. Lipases disintegrate molecular bonds of fats and oils. Proteases disintegrate protein molecular bonds, and some can even selectively disintegrate casein tempera. Cellulases disintegrate molecular bonds in cellulose impurities or aid the removal of impurities from cellulose, and so on. Deactivation of enzymes is an issue that requires due attention. Enzymes can be temporarily deactivated by a sudden change in $\mathrm{pH}$ or temperature so that both conditions for their action are not met. They can be also deactivated by organic solvents, which would not dissolve the paint and which can serve for their more complete physical removal. A possible spontaneous reactivation of enzymes remaining in the painted layer after cleaning is a topic receiving lots of attention. This topic often prevails in the personal evaluation of suitability of enzymes for cleaning of paint surfaces and in the assessment of potential hazard arising from their longterm use. In any case, enzymes are proteins with limited shelf life. The application of enzymes is not usually initially considered when removing surface coatings from a painted surface. However, they can be used if conventional methods (dry mechanical techniques, chelating agents, water with a modified $\mathrm{pH}$ level, tensides and solvents) do not yield satisfactory results. The following should be taken into consideration to evaluate the suitability of enzymes in the cleaning of paint surfaces: - What is the material to be removed, i.e. what are its dominant bonding forces (adhesion and cohesion)? - What is the binding medium of the layer that must not be damaged? - Which bonds are 4.1. Sample preparation

Selected samples were used to study and evaluate the effect of enzymes on stains, pigments, and organic media so as to select the most effective enzyme for cleaning the chosen cases. They were prepared in similar manner for different types of mural paintings. However, disintegrated by a specific enzyme?. The appropriate enzyme can be a very efficient and effective selective agent for removal of surface coatings that have strong molecular bonds. These are various temperas, albumen, animal glue, oil paint, lacquers and overpaints whose binding medium differs from that of the original colour. There are two prerequisites for the successful use of enzymes: 1. An analytical laboratory that provides reliable information to the conservator/restorer regarding the identification of binding media, both of the unwanted material and of the original. It would be logical to use the enzymes that break only the molecular bonds of the material to be removed and that exert no action on the matter to be preserved. However, this does not have to be this simple no.1. 2. The greatest problem in the use of enzymes for the cleaning of paint surfaces is that one should have stocks of fresh active enzymes in a refrigerator, i.e. various lipases, proteases, cellulases, all of which have a limited shelf life. When a particular enzyme proves efficient, either the quantity necessary for the entire job or the possibility of its purchase should be ensured. This may not be easy in the case of non-commercial laboratory samples. Enzymes are used in the field of materials conservation by many searchers such as Ramsay-O'Hoski, 1976 [10], Grattan et al., 1987 [11], Romão et al., 1990 [12], Larminie, 1992 [13], Saiz-Jimenez, 1997 [14], Bellucci et al.,1999 [15], Beutel et al., 2002 [16], Baink, 2003 [17], Turner et al., 2005 [18] Ranalli et al., 2005 [19], Cappitelli et al., 2006 [20], Webster and May, 2006 [21], Cappitelli et al., 2007, [22] and Ahmed, 2010), [23]

structural buildup, technique, and condition of mural paintings found in tombs, temples, monasteries, and churches (i.e. presence of stains) were considered during sample preparation stage. Mural paintings samples were prepared in cubes; common stains were 
applied on the surface to imitate the conditions of archaeological mural paintings. The following stains were added to the surface of the experimental samples: 1. Dust and dirt. 2. Old

\subsection{Enzymes cleaning study}

Two types of enzymes have been used for cleaning the surface of the experimental samples laboratory prepared Table (1) List of laboratory prepared enzymes and commercial enzymes

\section{Laboratory prepared enzymes}

1- Protease Bacillus Stearothermophilus (B.Staro)

2- Protease Bacillus Coagulans (B.Coag)

3- amylase isolated from chickens organic waist and feather ( B.5c)

4- amylase isolated from soymilk (B.Soyamilk) varnishes which were used as consolidates and is isolating materials. 3 . Soot layers which results from the burning of candles and incenses. 4. Blood of bats.

enzymes from bacteria and commercial enzymes [7], as listed in tab. (1).

\subsection{The effect of enzymes on the selected stains.}

Through the records obtained from the previous experiments that had been done for evaluating the effect of enzymes on different stains applied on mural painting sample, the following points could be conclude: $* B$. 5 c bacteria and B.Coag gave excellent results in removing blood stains from the prepared mural painting samples. * B. 5c bacteria and B. Staro bacteria gave excellent results in removing animal glue used to fix gauze to the surface of the experimental samples. * B. 5c bacteria and B. Soymilk bacteria gave excellent results in removing varnish from the surface of the experimental samples. $* B$. Coag bacteria and B. Staro bacteria gave commercial enzymes

1- Protease(P85968)

2- Protease (P5985)

3- Lipase (62301)

4- Lipase (L8525)

Table (2) Effect of laboratory prepared enzymes on the selected stains

\begin{tabular}{|l|c|c|c|c|}
\hline \multicolumn{1}{|c|}{ Enz. } & B. Stero & B. Coag & B. $\mathbf{5 c}$ & B. Soyamilk \\
\hline Stain & $* * * *$ & $* * *$ & $* * * * * *$ & $* *$ \\
\hline Varnish & $*$ & $*$ & $* * * * * *$ & $* * * * *$ \\
\hline Oil, Fatty & $* * * * * *$ & $*$ & $* *$ & $* * *$ \\
\hline Blood & $* * * * *$ & $* * * * *$ & $* *$ & $* * * *$ \\
\hline Soot & $* * * * *$ & $* * * * *$ & $* * * *$ & $* * *$ \\
\hline
\end{tabular}

Table 3: Effect of commercial enzymes on the selected stains.

\begin{tabular}{|l|c|c|c|c|c|c|}
\hline \multicolumn{1}{|c|}{ Enz. } & P1 & P2 & L1 & L2 & A1 & A2 \\
\hline Stain & P85968 & P5985 & 62301 & L8525 & A621) & A9857 \\
\hline Glue & $* * * * *$ & $* * * *$ & $* * * * *$ & $* * *$ & $* * * *$ & $* * *$ \\
\hline Varnish & $* * * *$ & $* * *$ & $* * * * *$ & $* * *$ & $* * * * *$ & $* * *$ \\
\hline Oil, Fatty & $* * *$ & $* *$ & $* * * * * *$ & $* * * * * *$ & - & - \\
\hline Blood & $* * * *$ & $* * *$ & - & $* *$ & $*$ & $* * *$ \\
\hline $\begin{array}{l}\text { Soot } \\
* * * * * *\end{array}$ Fast, & $* * * * *$ excellent, & $* * * *$ very good, & $* * *$ good, & $* *$ satisfactory, & $*$ poor \\
\hline
\end{tabular}




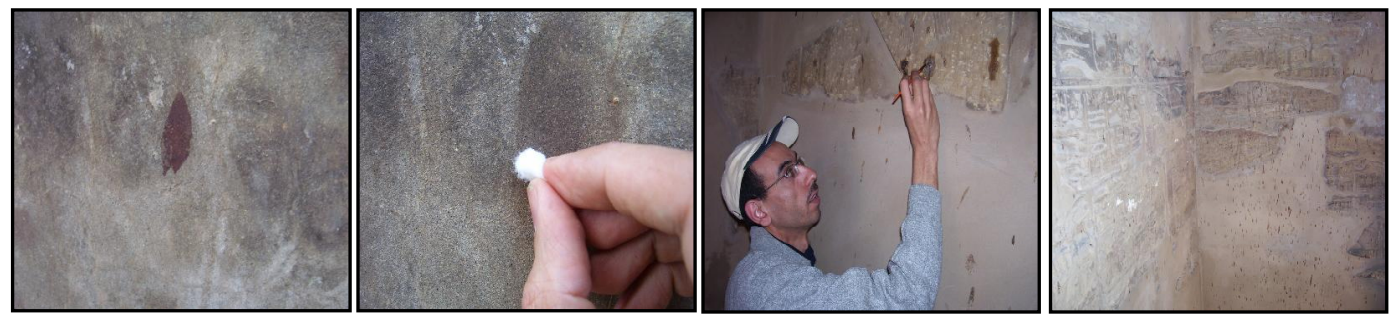

Figure (4) Results of application of enzymes for removal the blood batches from the Mortuary Temple of Ramses III wall paintings surface (1186-1155 BC, 20th dynasty) Egypt.

\subsection{Application of selected enzymes on real wall paintings surface}

The surface of mural painting contains often several disfiguring overlapping stains as shown in the cross section examination and the optical microscope examination images. For that reason, the use of an accurate and balanced enzyme cleaning technique is required. Results of the experimental study and enzyme activity measurements suggested that the B.5c bacterium is the best producing protease enzyme. The cleaning process was carried at noon at the optimum temperature for the enzyme which is $37^{\circ} \mathrm{C}$. From the results of the enzyme activity measurement of B.5c bacteria, 10.75 U/flask were used. This enzymes were applied as solutions (enzymes in sodium phosphate buffer, $\mathrm{pH}$ $=7$ ) with low concentration $(5 \mathrm{U} \mathrm{ml})$ as recommended [24]. The enzyme was

evenly spread on the stain area of the mural painting using a soft flexible brush. The cultural filtrate was left on the stain for a period of 10-15 minutes to partially dissolve the overlapping stains on varnish, animal glue, soot and blood of bats, figs. (5-a, b, c) \& (6-a, b, c). FTIR technique is applied to determine the functional groups present in the samples. The result of the studied samples before and after treatment with enzyme showed that animal glue was used a varnish layer. The spectra obtained for studied samples were compared with those of animal glue standards. FTIR and LOM results confirmed the stability of organic medium before and after enzymatic cleaning of different kind of patches, as shown in fig. (7).
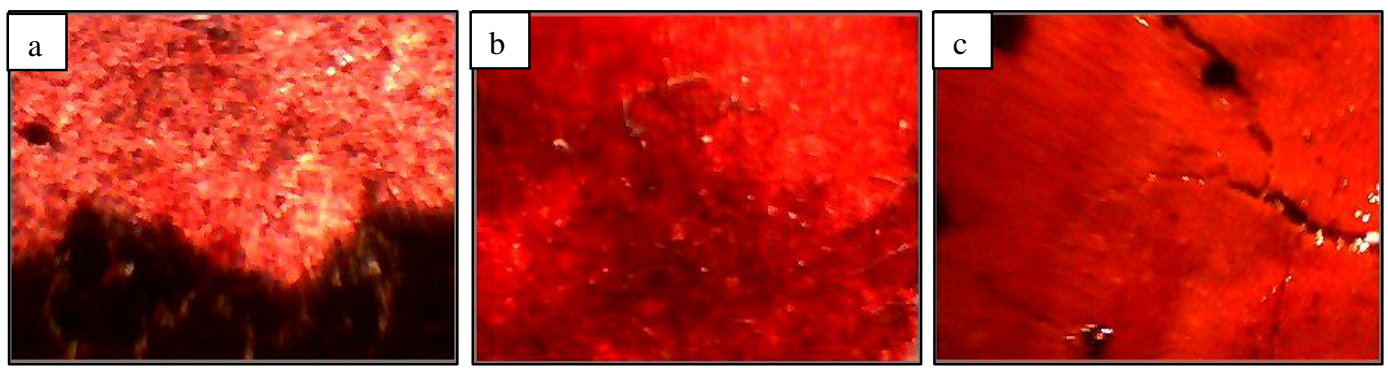

Figure (5-a, b, c) Optical microscopy results of application of Enzymes for removal the blood batches experimental samples.
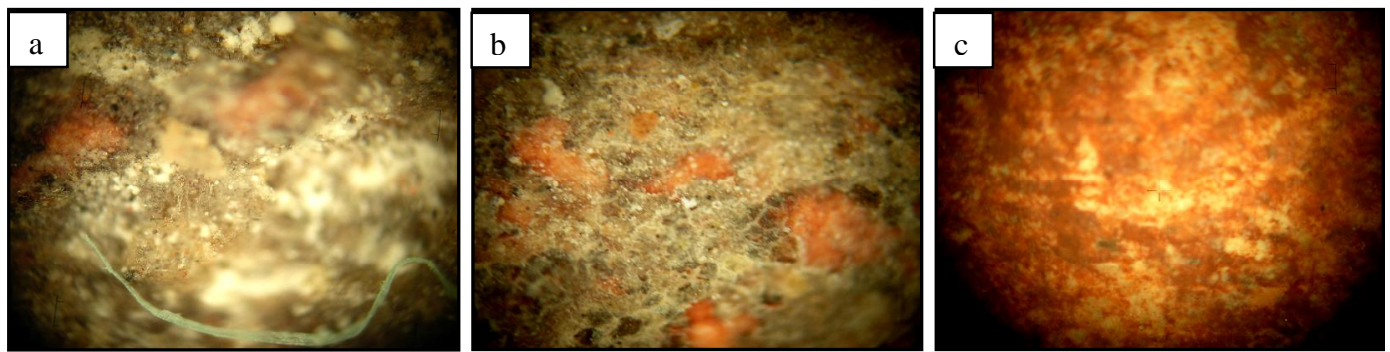

Figure (6-a, b, c) Optical microscopy results of application of enzymes for removal varnish and soot batches from real samples, a before application Enzymes, b during application. c. after removing the batches varnish and soot 


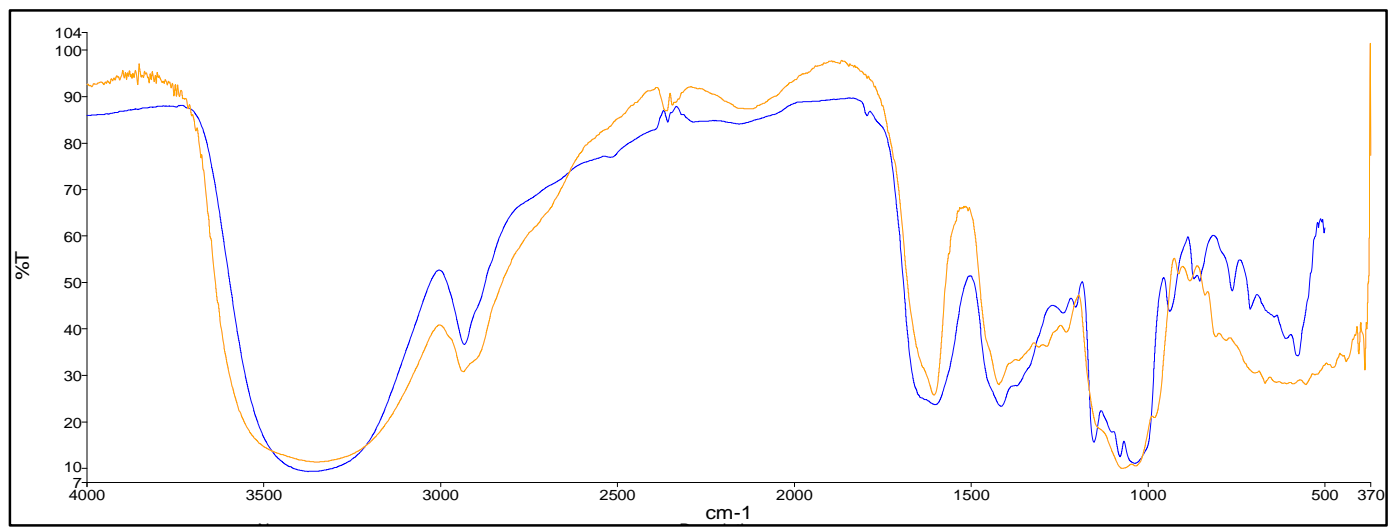

Figure (7) FTIR spectra of binder in wall paintings compared with Arabic gum spectra before and after cleaning with enzymes.

\section{Discussion}

Through the examination with optical microscopy of surface condition of the samples under study it could be clarified that all the samples suffer from significant deterioration in the condition and consistency of certain amount. Where the pictures show us how much damage output on the surface of soot and dust and salts to prevent see the colours as well as those of layers of old glue and varnishes. The small grain size of red pigment material (hematite) i.e. is less than $<1 \mu \mathrm{m}$ is result of grinding and well being of the colored soft dirt. Light microscope examination of cross sections of the painting samples under study revealed small thickness of the mural painting class under study (class colour), which do not exceed $10 \mu \mathrm{m}$ in thickness, making them fragile and susceptible to damage factors. Through the analyses in PIXE a sample under study is clear that red colour in the samples contain $\mathrm{Fe}$ (with pictures light microscopic examination of samples) leading to the

conclusion that the pigment is hematite. The blue pigment is Egyptian Blue. The use of enzymes for cleaning painted surfaces should not be regarded as an alternative to organic solvents, but rather as a relevant and powerful supplement. The use of enzymes as Crud enzymes (mixture of enzymes from the cultural filtrate) are much effective in removing the batches from the surfaces of wall paintings that is be cause the surface of wall paintings have multi and different batches mixture together on the surface (Varnishes + blood + soot and dirt), so to solve then remove it, its much better to use mixture of different multi enzymes together to help in dissolve the batches. These enzymes were applied as solutions (enzymes in sodium phosphate buffer, $\mathrm{pH}$ = 7) The obtained data from FTIR results showed that there were no significant differences can be seen in the FTIR spectra of organic binder before and after enzymatic cleaning.

\section{Conclusion}

The current paper focuses on the application of biotechnology on Egyptian wall painting in Ramses III temple, the experimental results show that enough diagnosis and analytical works must carried out prior to cleaning with enzyme to identify the mural painting compositions and avoid damaging the pigments and binding media via enzymes. The enzymes solution is very effective in removing the batches from the surfaces of wall paintings that have multi and different batches mixture together on the surface such as Varnishes, blood, soot and dirt, after the evaluation by different methods, the author concludes that mixture of multi enzymes together to help in dissolving the batches without no significant differences could be seen in the FTIR spectra of organic binder before and after enzymatic cleaning. 


\section{Reference}

[1] Murnane, J., (1980). United with eternity- A concise guide to the monuments of Medinet Habu, Oriental institute, University of Chicago, AUC Press. Cairo

[2] Breasted, J., (1909). History of Egypt, MacMillan publishing company, UK

[3] Kamil, J., (1973). Luxor: A Guide to ancient Thebes, Prentice Hall Press, UK

[4] Gonsior, B., Höfert, M. \& Raith, B., (1988). Investigation of samples of Leonardo's "Last supper" in Santa. Maria delle Grazie, Milano. using the Bochum proton microprobe in combination with proton induced. Xray emission (PIXE), in: Istituto Centrale per Il Restauro-Associazione Italiana Prove Non Distruttive (ed.). $2^{\text {nd }}$ Int. Conf. on non-destructive testing, micro analytical methods and environment evaluation for study and conservation of works of art, Perugia, pp 1 - 8

[5] Shaaban, A., Korman, A., Stonert, A., Muunik, F. \& Turos, A., (2009). VACUUM Journal, Vol. 83, pp: S4S8.

[6] Pages, S., (2004). Micro-PIXE and micro Raman spectroscopy applied to polychrome wooden altarpiece from the 16th century, Raman spectroscopy, Vol., 35, pp: 633-639

[7] Neelmeijer, C. \& Mäder, M, (2002). The merits of particle induced X-ray emission in revealing painting techniques, Nuclear Instruments and Methods in Physics Research B 189 (2002) 293-302

[8] Zucchiatti, A., (2004).

Characterization of early medieval frescoes by $\mu$-PIXE, SEM and Raman spectroscopy, Nuclear Instruments and Methods in Physics Research B, Vol. 219-220, pp. 20-25.

[9] Koen, H, (2004). Non-destructive microanalysis of cultural heritage materials, Elsevier, Amsterdam
[10] O'Hoski, B., (1976). Conservation information network, in: An investigation into the composition and properties of saliva in relation to the surface cleaning of oil paintings, Presented at the Ottawa regional group meeting, National Gallery of Canada, $14 \mathrm{p}$.

[11] Grattan, D, St. Hilaire, J., Burgess, H. \& McCawley, J., (1987). The characterization of enzymes for use in paper conservation, in: Petherbridge, G. (ed.) The conservation of library and archive materials and graphic arts, pp: 1524.

[12] Romão, P., Alarcão, A. \& Viana, C., (1990). Human salvia as a cleaning agent for dirty surfaces. Study in Conservation, Vol 35 (3), pp: 153-155.

[13] Larminie, P., (1992).The use of enzymes for the removal of oil stains from paper, in: Fairbrass, S. (ed.) Conference papers, Manchester, the Institute of Paper Conservation, pp: 119-122

[14] Saiz-Jimenez, C., (1997). Biodeterioration vs Biodegradation: the role of microorganisms in the removal of pollutants deposited on historic buildings. International biodeterioration \& biodegradation, Vol 40 (24), pp: 225-232.

[15] Belluci, R., Cremonesi, P. \& Pignagnoli, G., (1999). A preliminary note on the use of enzymes in conservation: the removal of aged acrylic resin coatings with lipase, Studies in Conservation, Vol. 44, pp: 278-281.

[16] Beutel, S., Klein, K., Knobbe, G., Königfeld, P., Petersen, K., Ulber, R. \& Scheper, T., (2002). Controlled enzymatic removal of damaging casein layers on medieval wall paintings. Biotechnology and Bioengineering Vol. 80 (1), pp: 1321.

[17] Gerhard, B., (2003). Removal of starch paste adhesives and relinings 
from paper-based objects by means of enzyme poultices, in: Materiali tradizionali ed innovativi nella pulitura dei dipinti e delle opere policrome mobili: atti del convegno, Piazzola su Brenta (PD), Padova, pp: 33-38.

[18] Turner, K., Serantoni, M., Boyce, A. \& Walsh, G., (2005). The uses of protease to remove portion-based residues from solid surface, Process Biochemistry, Vol. 40 (10), pp: 3377-3382.

[19] Ranalli, G., Alfano, G., Belli, C., Lustrato, G., Colombini, MP., Bonaduce, I., Zanardini, E., Abbruscato, P., Cappitelli, F. \& Sorlini, C., (2005). Biotechnology applied to cultural heritage: biorestoration of frescoes using viable bacterial cells and enzymes, Applied Microbiology, Vol. 98, pp: 73-83.

[20] Cappitelli, F., Zanardini, E., Ranalli, G., Mello, E., Daffonchio, D. \& Sorlini, C., (2006). Improved methodology for bioremoval of black crusts on historical stone artworks by use of sulfate-reducing bacteria, Applied and Environmental
Microbiology, Vol. 72, pp: 37333737.

[21] Webster, A., \& May, E. (2006). Bioremediation of weatheredbuilding stone surface, Trends in Biotechnology, Vol. 24, pp: 255260.

[22] Cappitelli, F., Toniolo, L., Sansonetti, A., Gulotta, D., Ranalli, G., Zanardini, E., \& Sorlini, C., (2007). Advantages of using microbial technology over traditional chemical technology in removal of black crusts from stone surfaces of historical monuments. Appl. Environ. Microbiol. Vol. 73, (17), pp: 5671- 5675.

[23] Ahmed, H., (2010). An extensive study of the effect of the enzyme $\alpha$ amylase used in textile conservation- on silk fibers dyed with safflower and madder dye. $E$ Conservation Magazine, Issue 17, pp: 41- 51

[24] Whaap, F., (2007). The treatment of two Coptic tapestry fragments. $V \& A$ Conservation Journal, No.55, pp: 11-13. 